\title{
Analisa Debit Banjir Rancangan DAS Tojo Metode HSS ITB 1
}

\author{
Aswar Amiruddin*1, Saparuddin ${ }^{2}$, T. Anasiru ${ }^{3}$ \\ ${ }^{1,2,3}$ Universitas Tadulako, Kampus Bumi Tadulako Tondo, Jalan Soekarno-Hatta Km.9 Palu, \\ Sulawesi Tengah \\ E-mail: *aswaramir89@gmail.com
}

Received 04 September 2020; Reviewed 07 September 2020; Accepted 13 October 2020 Journal Homepage: http://jurnal.borneo.ac.id/index.php/borneoengineering

\begin{abstract}
Floods often occur in several regions in Indonesia. The problem is the flooding with its uncertain characteristics is one of the environmental problems that has not been handled optimally. The method of converting rain data into discharge data for flood analysis has been widely presented in previous studies. The methods used to analyze flood discharge also vary, starting from rational, empirical, statistical models to unit hydrograph model. This research aims to determine the flood discharge design for return periods 2, 5, 10,20, 25, 50, and 100 years in Tojo watershed, Tojo Una-una Regency using the synthetic unit hydrograph method of ITB-1. Research methods are data collection and data analysis. Data collection was carried out at several agencies and collecting from online source. Results of this research design flood discharge that was analyzed by synthetic unit hydrograph of ITB-1 method. The maximum design flood discharge at Tojo watershed are $82.375 \mathrm{~m}^{3} / \mathrm{s}$ for a 2 -year, $98.21 \mathrm{~m}^{3} / \mathrm{s}$ for a 5 -year, $104.77 \mathrm{~m}^{3} / \mathrm{s}$ for a 10 -year, $111.83 \mathrm{~m}^{3} / \mathrm{s}$ for a 20 year, $113.3 \mathrm{~m}^{3} / \mathrm{s}$ for a 25 -year, $118.87 \mathrm{~m}^{3} / \mathrm{s}$ for a 50 -year, $123.86 \mathrm{~m}^{3} / \mathrm{s}$ for a 100-year return period.
\end{abstract}

Keywords: flood design analysis, synthetic unit hydrograph, return period, Tojo watershed

\begin{abstract}
Abstrak
Banjir semakin sering terjadi di beberapa wilayah di Indonesia. Permasalahan yang timbul adalah banjir dengan karakteristiknya yang penuh ketidakpastian merupakan salah satu masalah lingkungan yang hingga saat ini belum dapat ditangani secara optimal. Metode transformasi data hujan menjadi data debit untuk analisis banjir telah banyak disajikan pada penelitian terdahulu. Metode yang digunakan dalam menganalisis debit banjir juga beragam, mulai dari model rasional, empiris, statistik hingga model hidrograf satuan. Penelitian kali ini bertujuan menentukan debit banjir rancangan kala ulang 2, 5, 10, 20, 25, 50, dan 100 tahun pada DAS Tojo Kabupaten Tojo Una-una menggunakan metode hidrograf satuan sintetik ITB-1. Metode penelitian ini adalah pengumpulan data dan analisis data. Pengumpulan data dilakukan pada beberapa instansi dan diperoleh secara online. Analisis data pada penelitian kali ini adalah analisis debit banjir rancangan dengan metode hidrograf satuan sintetik (HSS) ITB-1. Berdasarkan hasil analisis debit banjir rancangan dengan metode HSS ITB-1 diperoleh debit banjir rancangan maksimum pada DAS Tojo adalah 82.375m3/dtk untuk kala ulang 2 tahun, $98.21 \mathrm{m3} / \mathrm{dtk}$ untuk kala ulang 5 tahun, $104.77 \mathrm{m3} / \mathrm{dtk}$ untuk kala ulang 10 tahun, $111.83 \mathrm{m3} / \mathrm{dtk}$ untuk kala ulang 20 tahun, $113.3 \mathrm{m3} / \mathrm{dtk}$ untuk kala ulang 25 tahun, $118.87 \mathrm{m3} / \mathrm{dtk}$ untuk kala ulang 50 tahun, $123.86 \mathrm{m3} / \mathrm{dtk}$ untuk kala ulang 100 tahun.
\end{abstract}

Kata kunci: Debit banjir rancangan, hidrograf satuan sintetik, kala ulang; DAS Tojo 


\section{Pendahuluan}

Banjir semakin sering terjadi di beberapa wilayah di Indonesia. Banjir didefinisikan sebagai peristiwa meluapnya air sungai melebihi tebing sungai (Savitri, 2017). Pengendalian banjir perlu dilakukan untuk menurunkan tingkat risiko kerugian baik kerugian harta benda maupun kerugian jiwa. Permasalahan yang timbul adalah banjir dengan karakteristiknya yang penuh ketidakpastian merupakan salah satu masalah lingkungan yang hingga saat ini belum dapat ditangani secara optimal. Estimasi puncak banjir yang terlalu besar atau terlalu kecil menyebabkan tidak efisiennya program penanggulangan banjir yang akan dilaksanakan, baik secara struktural maupun nonstruktural Oleh karena itu, diperlukan metode analisis banjir rancangan yang representatif untuk memperkirakan banjir dengan kinerja yang dapat diandalkan (Tunas, 2018).

Data terbaik yang digunakan dalam analisis debit banjir adalah rekaman data debit atau ketinggian muka air dari AWLR. Namun tidak semua sungai memiliki stasiun AWLR, sehingga debit banjir rancangan diperoleh dari analisis seri data curah hujan (Purnomo, 2017). Metode transformasi data hujan menjadi data debit untuk analisis banjir telah banyak disajikan pada penelitian terdahulu. Metode yang digunakan dalam menganalisis debit banjir juga beragam, mulai dari model rasional, empiris, statistik hingga model hidrograf satuan (Tunas, 2018). Hidrograf satuan didefinisikan sebagai hidrograf limpasan langsung (tanpa aliran dasar) yang tercatat di ujung hilir DAS yang ditimbulkan oleh hujan efektif sebesar $1 \mathrm{~mm}$ yang terjadi secara merata di permukaan DAS dengan intensitas tetap dalam suatu durasi tertentu (Taslim, 2019).

Beberapa model hidrograf satuan telah banyak dikembangkan seperti model Nakayasu, Snyder, SCS, Gama I, Limantara, ITB-1, ITB-2, ITS-1 dan ITS-2. Kinerja model-model hidrograf satuan sintetis ini terutama Snyder, SCS dan Nakayasu telah dievaluasi di Indonesia. Indonesia merupakan negara tropis sehingga memiliki karakteristik DAS dan curah hujan yang sangat berbeda dengan daerah tempat ketiga model tersebut dirumuskan, sehingga hasil analisis yang diperoleh kurang optimal (Tunas, 2019). Di Indonesia model hidrograf juga mulai dikembangkan oleh beberapa peneliti maupun akademisi seperti Gama 1, Limantara, ITB-1, ITB-2, ITS-1 dan yang terbaru ITS2 (Margini, 2017).

HSS Gama 1 dikembangkan oleh Sri Hartato (1993) berdasar perilaku hidrologis di 30 DAS di Pulau Jawa pada dekade 1980-an yang mengkombinasikan antara Metode Strahler dan pendekatan Kraijenhorr van der Leur (Oktarina, 2015). Sedangkan Limantara dikembangkan oleh Lily Montarcih dari universitas Brawijaya berdasarkan karakteristik beberapa DAS di Indonesia (Enung, 2019). Selanjutnya konsep dasar HSS ITB pertama kali dipublikasikan oleh Dantje Natakusumah. Model HSS ITB dikembangkan berdasarkan pengalaman saat evaluasi terhadap hidrograf banjir rencana suatu pengujian model fisik pelimpah bendungan Citepus dan bendungan Sadawarna pada tahun 2009 (Handayani, 2016). Selanjutnya Natakusumah dkk melakukan perbaikan prosedur umum perhitungan HSS ITB-1 dan ITB-2 pada 2010 (Natakusumah, 2011).

Parameter DAS yang diperlukan dalam penggunaan model HSS ITB-1 dan ITB-2 sangat sederhana yaitu luas DAS (A), panjang sungai utama (L) dan parameter non fisik $\mathrm{Ct}$ diperlukan sebagai kalibrasi (Natakusumah, 2011). Perbedaan antara HSS ITB-1 dan ITB-2 yakni pada persamaan bentuk hidrografnya, dimana HSS ITB-1 menggunakan persamaan lengkung naik dan lengkung turun seluruhnya yang dinyatakan dengan satu persamaan yang sama. Untuk HSS ITB-2 persamaan lengkung naik dan lengkung turun dinyatakan dengan dua persamaan yang berbeda (Natakusumah, 2011). 
Selanjutnya peneliti melakukan kajian debit banjir rancangan pada DAS Tojo Provinsi Sulawesi Tengah dengan menggunakan HSS ITB-1. Tujuan dari penelitian ini adalah untuk menentukan debit banjir DAS Tojo kala ulang 2, 5, 10, 20, 25, 50 dan 100 tahun dengan menggunakan metode HSS ITB-1.

\section{Metode Penelitian}

\subsection{Lokasi Penelitian}

Penelitian debit banjir rancangan HSS ITB-1 dilakukan pada Daerah Aliran Sungai (DAS) Tojo, Kabupaten Tojo Una-una, Provinsi Sulawesi Tengah. Secara geografis DAS Tojo terletak pada koordinat $1^{\circ} 17^{\prime} 29.26^{\prime \prime} \mathrm{LS}-1^{\circ} 28^{\prime} 22.44^{\prime \prime} \mathrm{LS}$ dan $121^{\circ} 11^{\prime} 38^{\prime \prime} \mathrm{BT}-121^{\circ} 24^{\prime} 25^{\prime \prime B T}$. Secara administratif DAS Tojo berbatasan dengan Teluk Tomini di sisi utara, kabupaten Morowali Utara di sisi selatan, kabupaten Poso di sisi Barat dan kota Ampana di sisi timur. Lokasi DAS Tojo dapat dilihat pada Gambar 1.

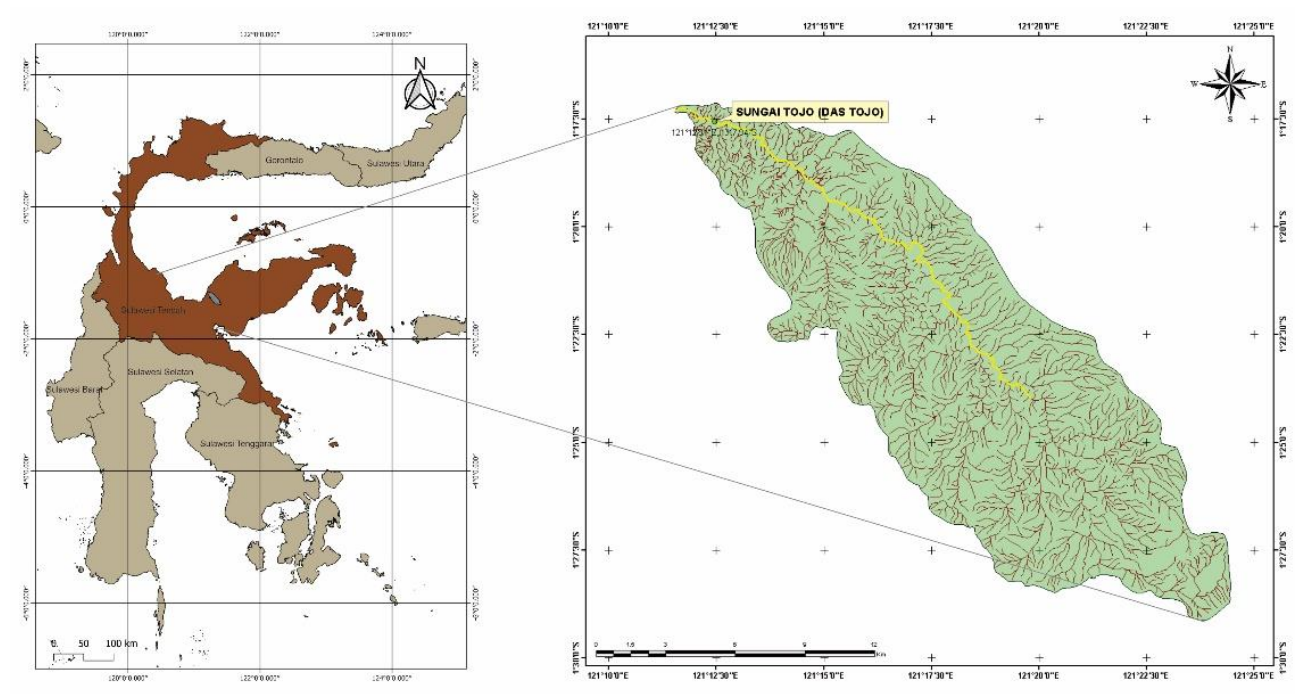

Gambar 1. Peta Lokasi Penelitian

\subsection{Data Penelitian}

Data yang digunakan pada penelitian ini adalah data yang dikumpulkan melalui beberapa instansi, yaitu: Demnas yang diperoleh secara online melalui demnas.big.go.id. Data curah hujan dari Dinas Cipta Karya dan Sumber Daya Air Provinsi Sulawesi Tengah. Peta Tutupan Lahan 2018 diperoleh secara online melalui halaman geoportal.menlhk.go.id.

\subsection{Analisis Data}

Tahapan analisis data pada penelitian kali ini terdiri dari beberapa tahapan yakni pertama, analisis batas das dengan menggunakan tools hydrology pada program arcgis. Analisis statistik dasar terhadap data hujan yang ada untuk menentukan metode yang digunakan dalam menganalisis hujan rancangan, selanjutnya menghitung hujan rancangan berdasarkan metode yang diperoleh pada analisis sebelumnya. Dari data hujan rancangan yang diperoleh dilakukan perhitungan terhadap intensitas hujan jam-jaman menggunakan metode Mononobe. Setelah memperoleh intensitas hujan 
jam-jam kemudian melakukan perhitungan HSS ITB-1 berdasarkan data karakteristik DAS Tojo dan hasil analisis intensitas hujan jam-jaman tersebut.

\section{Hasil dan Pembahasan}

\subsection{DAS Tojo}

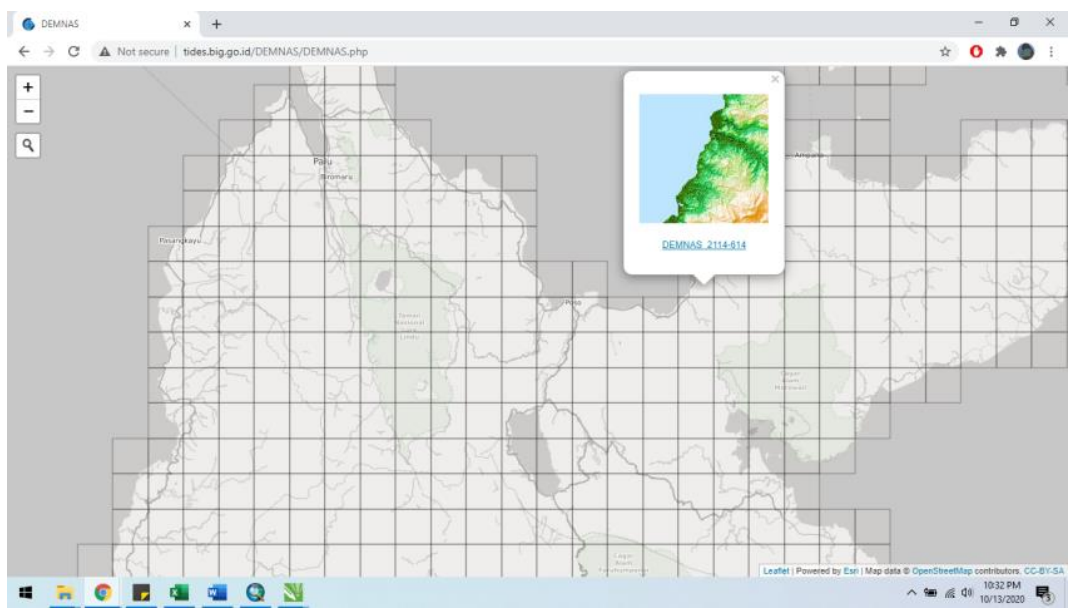

Gambar 2. Digital Elevation Model (DEMNAS) Wilayah Studi

Pada penelitian kali ini penentuan batas DAS dianalisis dengan Sistem Informasi Geografi (SIG). Penentuan batas DAS dilakukan menggunakan bantuan model Soil and Water Analysis Tools (SWAT). Data yang digunakan pada analisis batas DAS ini adalah data Digital Elevation Model (DEM) yang bersumber dari Digital Elevation Model Nasional (DEMNAS) Badan Informasi Geospasial (BIG). DEM Nasional (DEMNAS) dibangun dari beberapa sumber data meliputi data IFSAR (resolusi 5m), TERRASAR-X (resolusi 5m) dan ALOS PALSAR (resolusi 11.25m), dengan menambahkan data Masspoint hasil stereo-plotting (Tides.big.go.id). Untuk menganalisa batas DAS Tojo digunakan DEMNAS sebanyak 16 Nomor Lembar Peta (NLP). Gambar salah satu Nomor Lembar Peta (NLP) DEMNAS Lokasi Studi dapat dilihat pada Gambar 2.
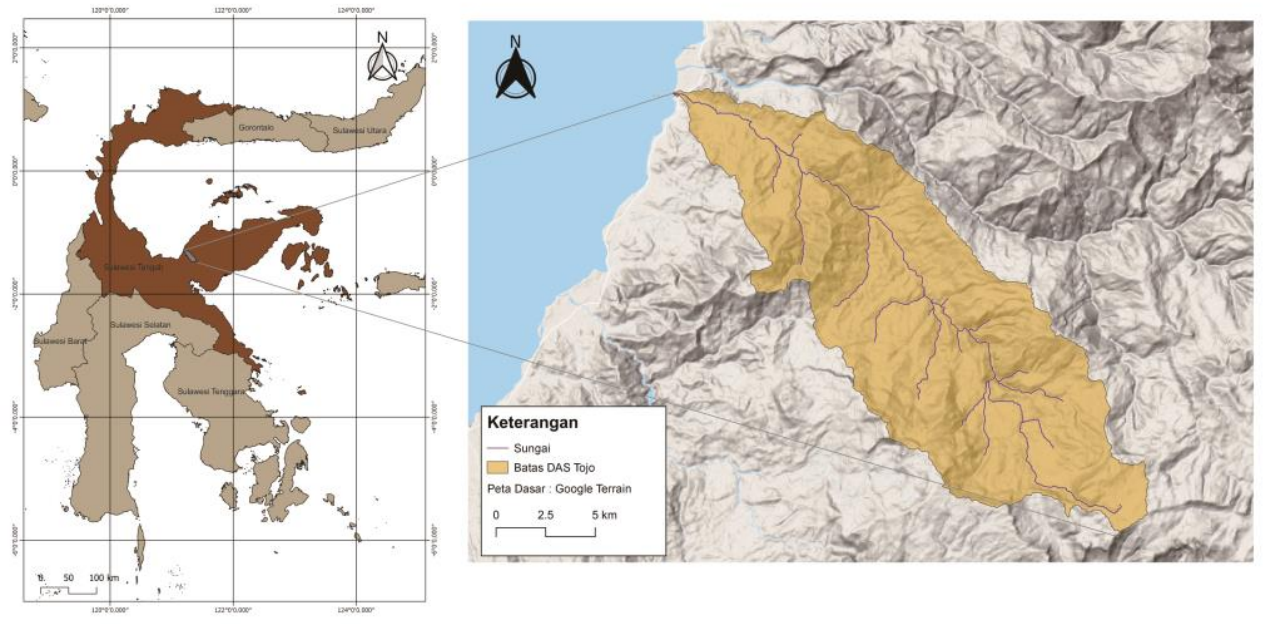

Gambar 3. Batas DAS Tojo 
Gambar 3 memperlihatkan batas Daerah Aliran Sugai (DAS) Tojo, Hasil analisis batas DAS dengan model SWAT diperoleh informasi lengkap tentang arah pengaliran (flow direction), akumulasi dari arah pengaliran (flow accumulation), aliran sungai (stream) dan batas Daerah Aliran Sungai (DAS). Berdasarkan analisis model SWAT juga diperoleh luasan Daerah Aliran Sungai (DAS) Tojo sebesar 21275 Ha.

\subsection{Tutupan Lahan DAS Tojo}

Berdasarkan peta batas DAS yang diperoleh pada analisis model SWAT diketahui luas Daerah Aliran Sungai (DAS) Tojo adalah 21275 Ha dengan panjang sungai utama $28 \mathrm{~km}$. Hasil deliniasi batas DAS kemudian di overlay di atas peta tutupan lahan KLHK tahun 2018 untuk memperoleh informasi kondisi tutupan lahan DAS Tojo. Berdasarkan hasil overlay diperoleh informasi tutupan lahan DAS Tojo masih didominasi oleh kawasan hutan baik itu kawasan hutan primer maupun hutan sekunder, hal ini terlihat dari peta tutupan lahan pada Gambar 4. Selanjutnya dilakukan interpretasi data luas kawasan hutan DAS Tojo. Hasil interpretasi pada peta tutupan lahan diperoleh persentase luas kawasan hutan terhadap luasan DAS pada DAS Tojo sebesar 73\% yakni sebesar 15530.75 ha.

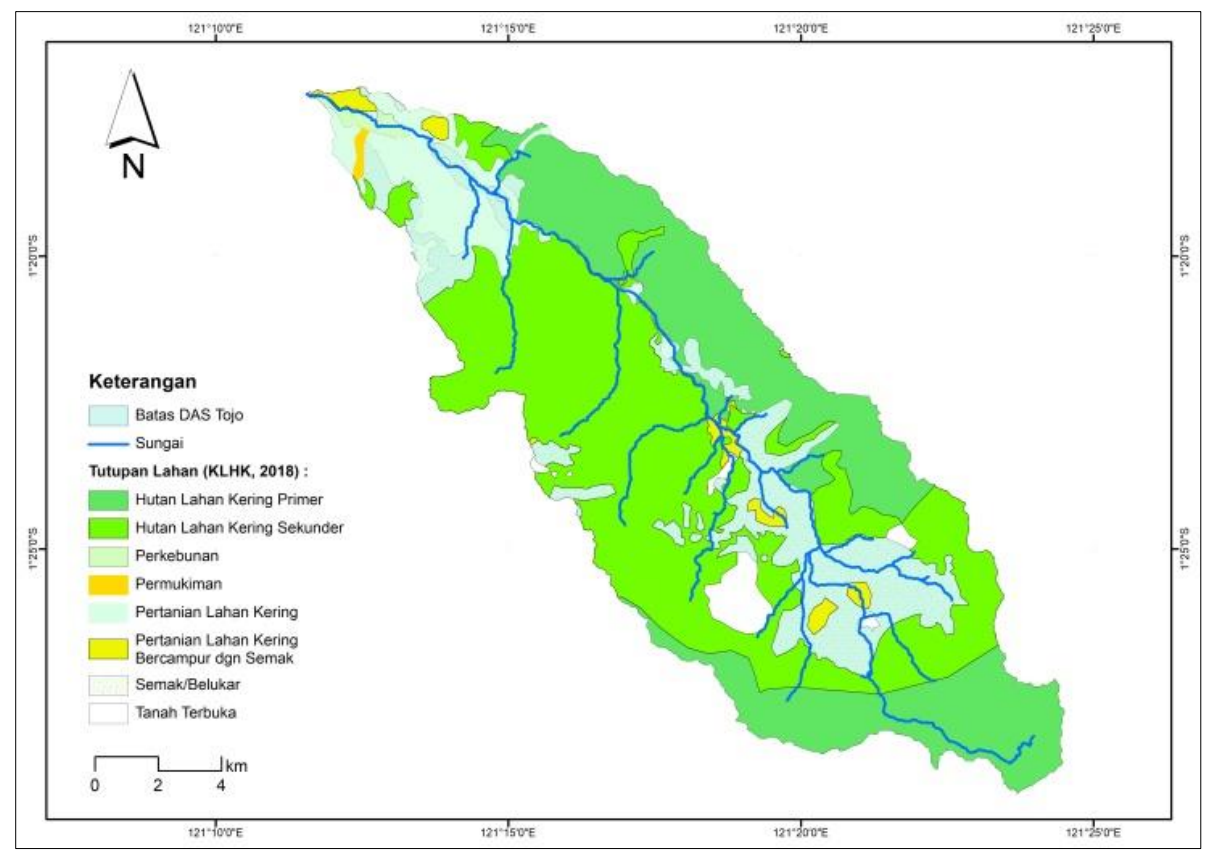

Gambar 4. Tutupan Lahan DAS Tojo

\subsection{Analisis Hidrologi}

\subsubsection{Hujan Harian Maksimum}

Data hujan yang digunakan pada penelitian DAS Tojo bersumber dari stasiun hujan Borone. Data hujan stasiun Borone merupakan data hujan maksimum harian tahun 2009-2019 (11 tahun). Data hujan harian kemudian dilakukan rekapitulasi terhadap data hujan maksimum bulanan. Rekapitulasi data hujan maksimum bulanan dapat dilihat pada Tabel 1. 
Tabel 1. Curah Hujan Maksimum Tahunan Stasiun Borone 2009-2019

\begin{tabular}{cccc}
\hline No & Tahun & Curah Hujan Maksimum $(\mathbf{m m})$ & Curah Hujan Terurut $(\mathbf{m m})$ \\
\hline 1 & 2009 & 53.5 & 97.1 \\
2 & 2010 & 58.7 & 81.4 \\
3 & 2011 & 70.8 & 78.0 \\
4 & 2012 & 76.5 & 76.5 \\
5 & 2013 & 81.4 & 72.0 \\
6 & 2014 & 46.8 & 70.8 \\
7 & 2015 & 78.0 & 70.4 \\
8 & 2016 & 72.0 & 64.2 \\
9 & 2017 & 97.1 & 58.7 \\
10 & 2018 & 70.4 & 53.5 \\
11 & 2019 & 64.2 & 46.8
\end{tabular}

Sumber : Hasil Analisis, 2020

Dari data hujan bulanan ini kemudian dilakukan pengujian statistik dasar untuk menentukan metode analisis frekuensi hujan yang akan digunakan. Berdasarkan hasil pengujian statistik dasar diperoleh hasil koefisien skewnes (Cs) adalah 0.17455, koefisien kurtois (Ck) adalah 2.2638 dan koefisien variasi $(\mathrm{Cv})$ adalah 0.1995 . Hasil pengujian statistik dasar ini kemudian dimasukkan ke dalam tabel tinjauan distribusi berdasarkan parameter statistik dasar seperti pada Tabel 2.

Tabel 2. Tinjauan distribusi berdasarkan parameter statistik data hujan

\begin{tabular}{cccc}
\hline Tipe Distribusi & Syarat Parameter Statistik & $\begin{array}{c}\text { Hasil } \\
\text { Parameter } \\
\text { Statistik }\end{array}$ & Keterangan \\
\hline Distribusi & $\mathrm{Cs} \approx 0$ & & Tidak \\
Normal & $\mathrm{Ck} \approx 3$ & $\mathrm{Cs}=0.17455$ & memenuhi \\
Distribusi Log & $\mathrm{Cs}=3 \mathrm{Cv}+\mathrm{Cv}^{3}$ & $\mathrm{Ck}=2.2638$ & Tidak \\
Normal & $\mathrm{Ck}=\mathrm{Cv}^{8}+6 \mathrm{Cv}^{6}+15 \mathrm{Cv}^{4}+16 \mathrm{Cv}^{2}+3$ & $\mathrm{Cv}=0.1995$ & memenuhi \\
Distribusi & $\mathrm{Cs}=1.14$ & & Tidak \\
Gumbel & $\mathrm{Ck}=5.4$ & memenuhi \\
Log Pearson & Karena tidak ada nilai yang memenuhi dari ketiga kriteria di atas maka tipe \\
Type III & sebaran dianggap mengikuti tipe distribusi Log Pearson III \\
\hline
\end{tabular}

Sumber : Hasil analisis, 2020

Berdasarkan tabel tinjauan analisis parameter statistik dasar maka dapat disimpulkan untuk analisis frekuensi hujan dilakukan dengan metode Log Pearson III.

\subsubsection{Analisis Log Pearson III}

Berdasarkan hasil analisis statistik data hujan menggunakan parameter log dari data hujan harian maksimum diperoleh parameter-parameter sebagai berikut :
Jumlah Data (n)
$: 11$
Log X Rata-rata $\left(\log X_{\text {rata2 }}\right) \quad: 1.8367$
Standar Deviasi (Sd) : 0.0889
Koef. Skewness (Cs) : : -0.3679
Koef Kurtois (Ck) $\quad: 2.1607$
Koef Variasi $(\mathrm{Cv}) \quad: 0.0484$

Parameter-parameter di atas kemudian digunakan menghitung curah hujan terdistribusi menggunakan metode Log Pearson III berdasarkan periode ulang rencana 2, 5, 10, 20, 25, 50, dan 100 Tahun dan dapat dilihat pada Tabel 3. 
Tabel 3. Hasil Analisis Distribusi Hujan Metode Log Pearson III

\begin{tabular}{cccccc}
\hline $\mathbf{T}$ & $\mathbf{P}(\boldsymbol{\%})$ & $\mathbf{C s}$ & $\mathbf{G}$ & $\mathbf{L o g} \mathbf{X}$ & $\mathbf{X}(\mathbf{m m})$ \\
\hline 2 & 50 & -0.3679 & 0.0609 & 1.8421 & 69.5146 \\
5 & 20 & -0.3679 & 0.8544 & 1.9126 & 81.7755 \\
10 & 10 & -0.3679 & 1.2355 & 1.9465 & 88.4116 \\
20 & 5 & -0.3679 & 1.5541 & 1.9748 & 94.3713 \\
25 & 4 & -0.3679 & 1.6179 & 1.9805 & 95.6106 \\
50 & 2 & -0.3679 & 1.8520 & 2.0013 & 100.3043 \\
100 & 1 & -0.3679 & 2.0531 & 2.0192 & 104.5198 \\
\hline
\end{tabular}

Sumber : Hasil Analisis, 2020

\subsubsection{Uji kesesuaian distribusi Chi-kuadrat}

Uji chi-kuadrat pada analisis data statistik bertujuan untuk menentukan apakah persamaan distribusi peluang yang telah dipilih dapat mewakili dari distribusi statistik sampel yang dianalisis. Hasil pengujian chi-kuadrat metode Log Pearson III dapat dilihat pada Tabel 4. dan Tabel 5.

Tabel 4. Besar peluang dan nilai batas kelas Log Pearson III

\begin{tabular}{ccccc}
\hline $\mathbf{P}(\boldsymbol{\%})$ & $\mathbf{C s}$ & $\mathbf{G}$ & $\mathbf{L o g} \mathbf{X}$ & $\mathbf{X}(\mathbf{m m})$ \\
\hline 20 & -0.3679 & 0.8544 & 1.9126 & 81.7755 \\
40 & -0.3679 & 0.3254 & 1.8656 & 73.3824 \\
60 & -0.3679 & -0.2323 & 1.8160 & 65.4656 \\
80 & -0.3679 & -0.8186 & 1.7639 & 58.0614 \\
\hline
\end{tabular}

Sumber : Hasil Analisis, 2020

Tabel 5. Perhitungan uji Chi-kuadrat Log Pearson III

\begin{tabular}{|c|c|c|c|c|c|c|c|c|c|}
\hline \multirow{2}{*}{ No. } & \multirow{2}{*}{\multicolumn{5}{|c|}{ Nilai Batas Sub Kelas }} & \multicolumn{2}{|c|}{ Jumlah Data } & \multirow{2}{*}{$(\mathrm{OF}-\mathrm{EF})^{2}$} & \multirow{2}{*}{$\begin{array}{c}(\mathrm{OF}- \\
\mathbf{E F})^{2} / \mathbf{E F}\end{array}$} \\
\hline & & & & & & OF & $\mathbf{E F}$ & & \\
\hline 1 & $\mathrm{X}$ & & $<$ & & 58.061 & 2.000 & 2.200 & 0.040 & 0.018 \\
\hline 2 & 58.061 & $<$ & $\mathrm{X}$ & $<$ & 65.466 & 2.000 & 2.200 & 0.040 & 0.018 \\
\hline 3 & 65.466 & $<$ & $X$ & $<$ & 73.382 & 3.000 & 2.200 & 0.640 & 0.291 \\
\hline 4 & 73.382 & $<$ & $\mathrm{X}$ & $<$ & 81.776 & 3.000 & 2.200 & 0.640 & 0.291 \\
\hline 5 & $\mathrm{X}$ & & $>$ & & 81.776 & 1.000 & 2.200 & 1.440 & 0.655 \\
\hline & & $\mathrm{uml}$ & ah: & & & 11 & 11 & 2.800 & 1.273 \\
\hline
\end{tabular}

Sumber : Hasil Analisis, 2020

Keterangan :

$\begin{array}{ll}\mathrm{OF} & =\text { Nilai Pengamatan } \\ \mathrm{EF} & =\text { Nilai Teoritis } \\ \mathrm{X}_{\text {hitung }}^{2} & =1.273 \\ \mathrm{DK} & =\mathrm{K}-(\mathrm{P}+1)\end{array}$

$\mathrm{K}$ (jumlah kelas) $=5$

$\mathrm{P}$ (parameter yang terikat dalam agihan frekuensi $)=2$

Untuk : $\mathrm{DK}=2$ dan $\alpha=5 \%$----> $\mathrm{X}_{\mathrm{cr}}^{2}=5.991$ (Tabel Chi-kuadrat)

Karena $\mathrm{X}_{\text {hitung }}^{2}<\mathrm{X}_{\mathrm{cr}}^{2} \rightarrow$ distribusi frekuensi dapat diterima 
Berdasarkan hasil uji kesesuaian distribusi hujan metode Chi-kuadrat, diperoleh kesimpulan bahwa distribusi frekuensi hujan dengan metode Log Pearson III dapat diterima, sehingga data hujan rancangan yang akan digunakan dalam menganalisis hidrograf merupakan data hasil analisis frekuensi Log Pearson III dapat dilihat pada Tabel 6.

Tabel 6. Rekap curah hujan rancangan

\begin{tabular}{ccc}
\hline No. & Kala Ulang (tahun) & Distribusi Log Pearson Tipe III (mm) \\
\hline 1 & 2 & 69.515 \\
2 & 5 & 81.776 \\
3 & 10 & 88.412 \\
4 & 20 & 94.371 \\
5 & 25 & 95.611 \\
6 & 50 & 100.304 \\
7 & 100 & 104.520 \\
\hline
\end{tabular}

Sumber : Hasil Analisis, 2020

\subsubsection{Hujan jam-jaman}

Analisis intensitas hujan jam-jaman dapat dilakukan dengan menggunakan beberapa metode, seperti mononobe, hasper dan weduwen. Analisis intensitas hujan jam-jaman pada penelitian kali ini menggunakan metode mononobe. Hasil analisis hujan jam-jaman metode mononobe dapat dilihat pada Tabel 7.

Tabel 7. Analisis hujan jam-jaman

\begin{tabular}{ccccccccc}
\hline \multirow{2}{*}{$\begin{array}{l}\text { Waktu } \\
\text { (jam) }\end{array}$} & \multirow{2}{*}{$\mathbf{R t}$} & \multicolumn{7}{c}{ Curah hujan rencana $(\mathbf{m m})$, Periode Ulang (tahun) } \\
\cline { 3 - 9 } & & $\mathbf{2}$ & $\mathbf{5}$ & $\mathbf{1 0}$ & $\mathbf{2 0}$ & $\mathbf{2 5}$ & $\mathbf{5 0}$ & $\mathbf{1 0 0}$ \\
\hline 1 & $34.668 \%$ & 6.025 & 7.087 & 7.663 & 8.179 & 8.287 & 8.693 & 9.059 \\
2 & $21.840 \%$ & 3.795 & 4.465 & 4.827 & 5.153 & 5.220 & 5.476 & 5.707 \\
3 & $11.494 \%$ & 1.997 & 2.350 & 2.540 & 2.712 & 2.747 & 2.882 & 3.003 \\
4 & $7.941 \%$ & 1.380 & 1.623 & 1.755 & 1.873 & 1.898 & 1.991 & 2.075 \\
5 & $6.151 \%$ & 1.069 & 1.258 & 1.360 & 1.451 & 1.470 & 1.542 & 1.607 \\
6 & $5.071 \%$ & 0.881 & 1.037 & 1.121 & 1.197 & 1.212 & 1.272 & 1.325 \\
7 & $4.347 \%$ & 0.755 & 0.889 & 0.961 & 1.026 & 1.039 & 1.090 & 1.136 \\
8 & $3.825 \%$ & 0.665 & 0.782 & 0.846 & 0.903 & 0.914 & 0.959 & 1.000 \\
\multicolumn{2}{l}{ Hujan Rancangan } & 69.515 & 81.776 & 88.412 & 94.371 & 95.611 & 100.304 & 104.520 \\
\multicolumn{2}{r}{ Koef. Limpasan } & 0.25 & 0.25 & 0.25 & 0.25 & 0.25 & 0.25 & 0.25 \\
\multicolumn{2}{c}{ Hujan Efektif } & 17.379 & 20.444 & 22.103 & 23.593 & 23.903 & 25.076 & 26.130 \\
\hline
\end{tabular}

Sumber : Hasil Analisis3.4 Analsis hidrograf ITB-1

\subsubsection{HSS tidak berdimensi dan HSS berdimensi}

Hidrograf satuan sintentik ITB-1 (HSS ITB-1) tidak berdimensi dan HSS ITB-1 berdimensi dianalisis berdasarkan beberapa parameter. Parameter-parameter yang dianalisis dapat dilihat pada Tabel 8 . 
Tabel 8. Parameter HSS ITB-1

\begin{tabular}{|c|c|c|c|}
\hline Parameter & Notasi & Rumus & Nilai (unit) \\
\hline Luas DAS & $\mathrm{A}_{\text {DAS }}$ & & $212.75 \mathrm{~km}^{2}$ \\
\hline Panjang sungai utama & $\mathrm{L}$ & & $28 \mathrm{~km}$ \\
\hline Tinggi hujan & & & $1 \mathrm{~mm}$ \\
\hline Durasi hujan & $\mathrm{T}_{\mathrm{r}}$ & & 1 jam \\
\hline Koefisien waktu & $\mathrm{C}_{\mathrm{t}}$ & & 1.1 \\
\hline Time lag & $t_{p}$ & $\mathrm{C}_{\mathrm{t}} \times 0.8122 \times \mathrm{L}^{0.6}$ & 6.597 jam \\
\hline Lama hujan efektif & $\mathrm{t}_{\mathrm{e}}$ & $\mathrm{t}_{\mathrm{p}} / 5.5$ & $1.199 \mathrm{jam}$ \\
\hline Waktu puncak & $\mathrm{T}_{\mathrm{p}}$ & $\begin{array}{l}\mathrm{t}_{\mathrm{e}}>\mathrm{T}_{\mathrm{r}}, \text { maka } \mathrm{T}_{\mathrm{p}}=\mathrm{t}_{\mathrm{p}}+0.25\left(\mathrm{~T}_{\mathrm{r}}-\mathrm{t}_{\mathrm{e}}\right) \\
\mathrm{t}_{\mathrm{e}}<\mathrm{T}_{\mathrm{r}}, \text { maka }_{\mathrm{T}}=\mathrm{t}_{\mathrm{p}}+0.5 \mathrm{~T}_{\mathrm{r}}\end{array}$ & 6.547 jam \\
\hline $\begin{array}{l}\text { Waktu dasar } \\
\text { Luas HSS }\end{array}$ & $\begin{array}{c}\mathrm{T}_{\mathrm{b}} \\
\mathrm{A}_{\mathrm{HSS}}\end{array}$ & $20 \times \mathrm{T}_{\mathrm{p}}$ & $\begin{array}{c}130.944 \text { jam } \\
1.692 \mathrm{~m}^{2}\end{array}$ \\
\hline Debit puncak & $\mathrm{Q}_{\mathrm{p}}$ & $Q_{p}=\left(\frac{R}{3.6 T_{p}}\right)\left(\frac{A_{D A S}}{A_{H S S}}\right)$ & $5.336 \mathrm{~m}^{3} / \mathrm{det}$ \\
\hline Persamaan bentuk kurva & $q(t)$ & $e^{\left\{2-t-\frac{1}{t}\right\}^{\alpha C p}}$ & \\
\hline
\end{tabular}

Sumber : Natakusumah dkk, 2011

Berdasarkan parameter-parameter di atas kemudian dianalisis hidrograf satuan sintentik ITB-1 (HSS ITB-1) tak berdimensi dan HSS ITB-1 berdimensi seperti ditunjukkan pada Gambar 4. dan Gambar 5.

BENTUK TIPIKAL HIDROGRAF SATUAN SINTETIS, TAK BERDIMENSI (METODE HSS ITB-1)

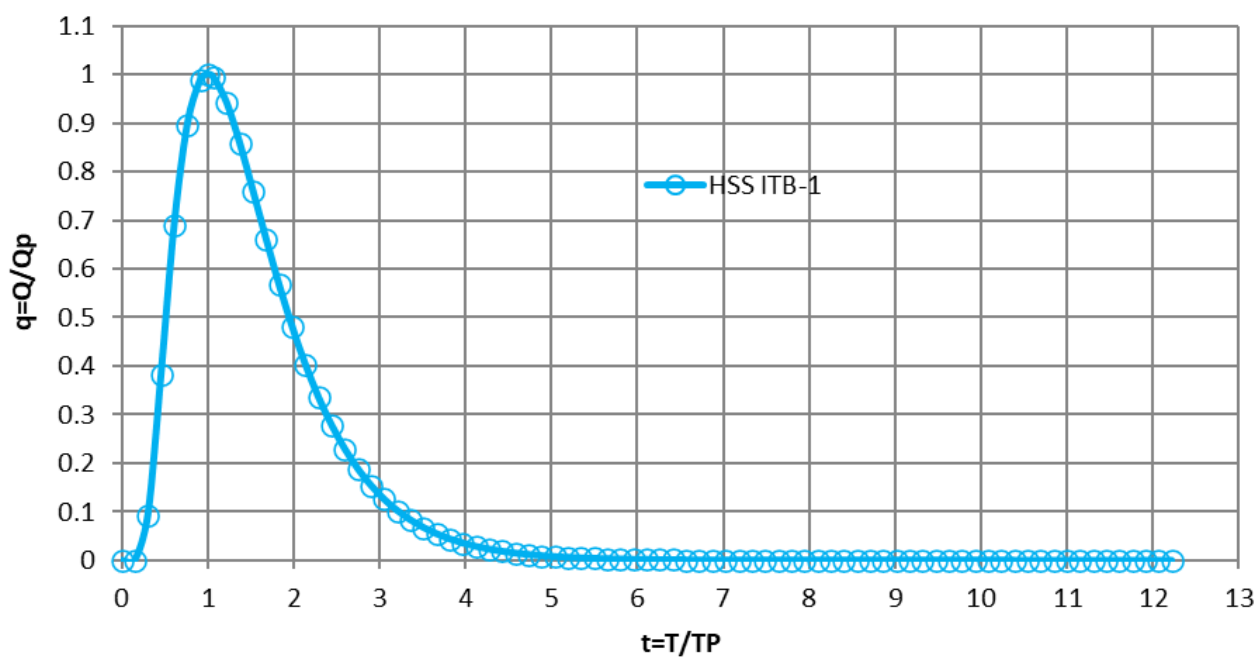

Gambar 4. HSS tidak berdimensi ITB-1 DAS Tojo (Hasil Analisis, 2020) 


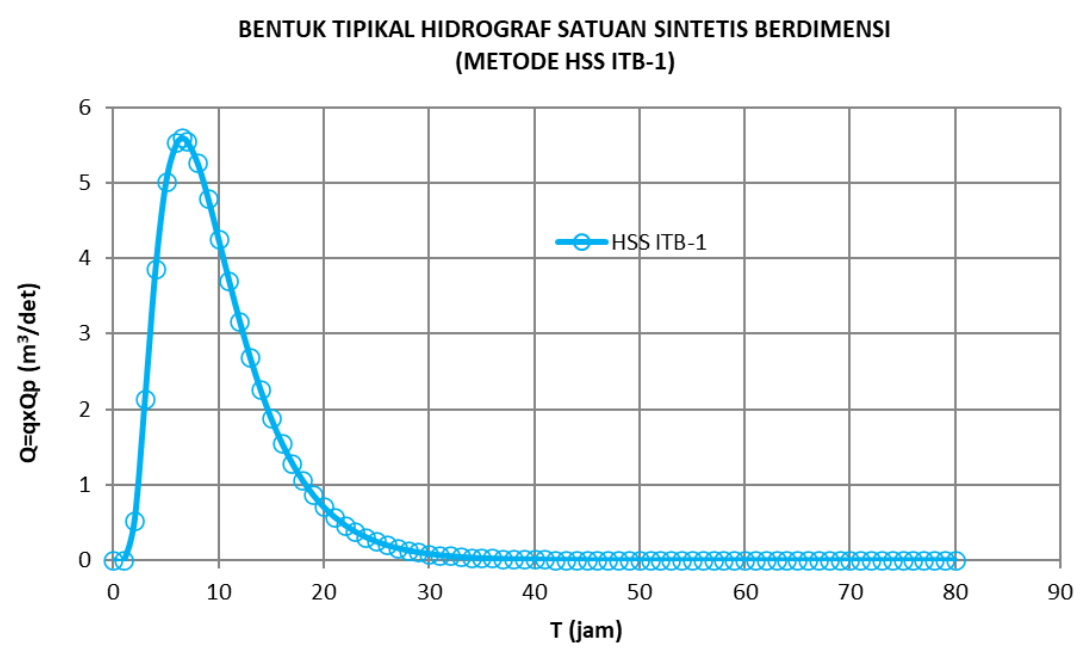

Gambar 5. HSS berdimensi ITB-1 DAS Tojo (Hasil Analisis, 2020)

\subsubsection{Debit banjir rancangan HSS ITB-1}

Berdasarkan hasil analisis hidrograf satuan sintentik (HSS) ITB-1 berdimensi di atas, dilakukan analisis debit banjir rancangan HSS ITB-1 untuk kala ulang 2, 5, 10, 20, 25, 50, 100 tahun. Hasil analisis debit banjir rancangan DAS Tojo dapat dilihat pada Gambar 6 dan Tabel 9.

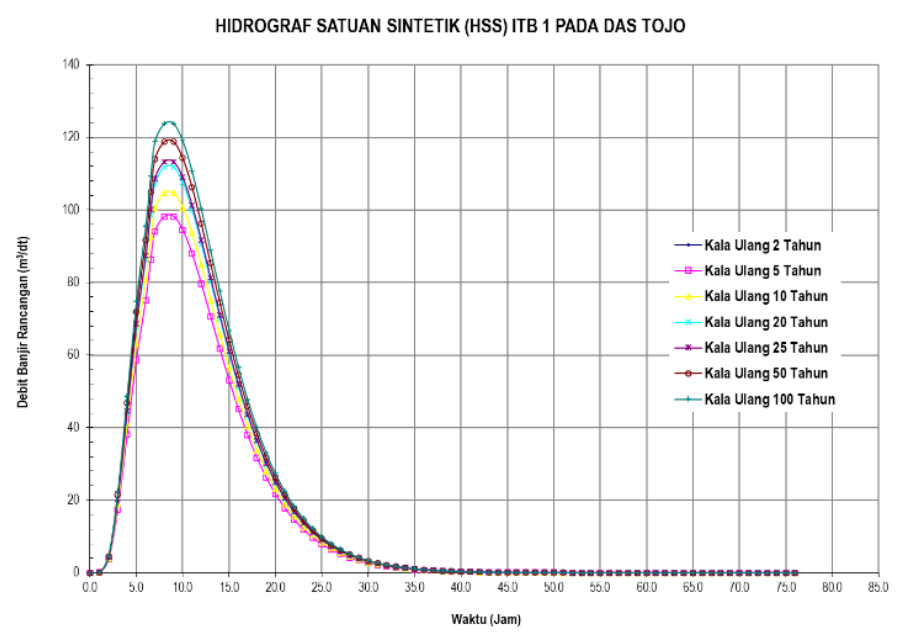

Gambar 6. Hidrograf banjir rancangan DAS Tojo metode HSS ITB-1periode ulang $2,5,10$, 20, 25, 50 dan 100 tahun (Hasil Analisis, 2020)

Tabel 9. Debit banjir rancangan DAS Tojo

\begin{tabular}{ccc}
\hline No. & Periode Ulang (tahun) & Debit Banjir $\left(\mathbf{m}^{\mathbf{3}} / \mathbf{d e t}\right)$ \\
\hline 1 & 2 & 82.3750 \\
2 & 5 & 98.2054 \\
3 & 10 & 104.7681 \\
4 & 20 & 111.8303 \\
5 & 25 & 113.2989 \\
6 & 50 & 118.8609 \\
7 & 100 & 123.8563 \\
\hline
\end{tabular}

Sumber : Hasil Analisis, 2020 


\section{Kesimpulan}

Berdasarkan analisis debit banjir rancangan dengan menggunakan metode hidrograf satuan sintetik (HSS) ITB-1 diperoleh debit banjir untuk DAS Tojo untuk kala ulang 2 tahun adalah 82.375 m3/det, kala ulang 5 tahun $98.2054 \mathrm{~m} 3 /$ det, kala ulang 10 tahun $104.7681 \mathrm{~m} 3 / \mathrm{det}$, kala ulang 20 tahun $111.8303 \mathrm{~m} 3 / \mathrm{det}$, kala ulang 25 tahun $113.2989 \mathrm{~m} 3 / \mathrm{det}$, kala ulang 50 tahun 118.8609 $\mathrm{m} 3 /$ det, kala ulang 100 tahun $123.8563 \mathrm{~m} 3 /$ det.

\section{Ucapan Terima Kasih}

Penulis mengucapkan terima kasih kepada semua yang terlibat pada penelitian kali ini. Fakultas Teknik Universitas Tadulako yang mempercayakan tim peneliti untuk memperoleh dana penelitian melalui pembiayaan DIPA Fakultas. Dinas Cipta Karya dan Sumber Daya Air Provinsi Sulawesi Tengah yang bersedia memberikan data hujan Borone dan peta batas DAS Tojo dalam bentuk shapefile.

\section{Daftar Pustaka}

Badan Informasi Geospasial, Digital Elevation Model, http://tides.big.co.id, diakses : 21 Mei 2020

Enung, 2016, Perencanaan Program Aplikasi Hidrograf Satuan Sintetik (HSS) dengan Metode Gama 1, Nakayasu, dan HSS ITB 1, Potensi : Jurnal Sipil Politeknik Vol. 18 (1) hal 08-20

Handayani, R, Fauzi, M, Hendri, A, 2016, Analisis Besaran Hidrograf Satuan Berdasarkan Karakteristik Daerah Aliran Sungai Siak, Jom FTEKNIK Vol. 3 No. 2

Kementerian Lingkungan Hidup dan Kehutanan, Peta Tutupan Lahan Indonesia Tahun 2018, http://geoportal.menlhk.go.id, diakses : 07 Juni 2020

Limantara, LM, 2009, Hidrograf Satuan Sintetik Limantara (Studi kasus di sebagian DAS Indonesia), Jurnal Rekayasa Sipil, Vol. 3 No. 3, ISSN: 1978 - 5658

Margini, NF, Nusantara, DAD, Ansori, MB, 2017, Analisa Hidrograf Satuan Sintetik Nakayasu dan ITB Pada Sub DAS Konto, Jurnal Teknik Hidroteknik Vol 2 No. 1, p-ISSN: 19799764

Natakusumah, D, Hatmoko, W, dan Harlan, D, 2011, Prosedur Umum Perhitungan Hidrograf Satuan Sintetik dengan Cara ITB dan Beberapa Contoh Penerapannya. Jurnal Teknik Sipil Vol. 18 No. 3

Oktarina, NR, 2015, Analisis Hidrograf Limpasan Akibat Variasi Intensitas Hujan dan Kemiringan Lahan (Kajian Laboratorium dengan Simulator Hujan), Jurnal Teknik Sipil dan Lingkungan Vol. 3 No. 1

Purnomo, SN, 2017, Pengaruh Metode Pemilihan Data Hujan Pada Perancangan Debit Banjir di DAS Serayu, Jurnal Techno, Vol. 18 No. 1, Hal 050-058, ISSN: 1410 - 8607

Savitri, E, Pramono, IB, 2017, Analisis Banjir Cimanuk Hulu, Jurnal Penelitian Pengelolaan Daerah Aliran Sungai, Vol. 1 (2), ISSN: 2579-5511 
Tunas, IG, 2018, Anwar, N, “A Flood Forecasting Model Based on Synthetic Unit Hydrograph of ITS-2" dalam prosiding $2^{\text {nd }}$ Borneo International Conference on Applied Mathematics and Engineering (Balikpapan, 10-11 Desember 2018)

Tunas, IG, 2019, Performance of Flood Prediction Model in Tropical Ricer Basin, Indonesia : A Synthetic Unit Hydrograph-based Evaluation, Disaster Advance, No. 12, page 26-37

Taslim, F, Sukarno, Hendratta, LA, 2019, Analisis Kapasitas Penampang Sungai Ongkag Dumoga dengan Metode HSS ITB dan HEC-RAS, Jurnal Sipil Statik, Vol. 7 No. 8, hal 923-932, ISSN: 2337-6732 